\title{
PENGEMBANGAN PERANGKAT ASESMEN AUTENTIK DALAM PEMBELAJARAN PENDIDIKAN KEWARGANEGARAAN
}

\author{
Abdul Basit \\ Program Studi PGSD Universitas Panca Marga \\ email:abdulbasit@upm.ac.id \\ Ludfi Arya Wardana \\ Jl. Yos Sudarso No.107, Pabean, Dringu, Probolinggo, Jawa Timur \\ email:ludfiaryawardana@upm.ac.id \\ Program Studi Pendidikan Kewarganegaraan Universitas Panca Marga
}

\begin{abstract}
The purpose of writing is to describe the procedure of this development is to produce products such as assessment tools consisting of authentic assessment guidelines, student activity sheet and recapitulation software to teachers for students of Class V semesters I. Eligibility of products based on the level of validity of the experts, the level of implementation and a high reading level through product trials. Data collection instruments used include sheet validation experts, questionnaire responses of students and teacher feedback questionnaire. The findings of the research and development show that the results of the validation test experts expressed very valid with an average score of 4.11. The level of implementation of products with an average score of 4.27. reading level product with an average score of 4
\end{abstract}

Keyword: AsesmenAutentik, PembelajaranPKn

\begin{abstract}
Abstrak:Tujuan penulisan adalah mendeskrisikan prosedur pengembangan ini yaitu untuk menghasilkan produk berupa perangkatasesmenyang terdiri dari panduanasesmenautentik, lembarkegiatansiswadansoftwarerekapitulasi untuk guru yang diperuntukkan bagi siswa Kelas V semester I. Kelayakan produk dinilai berdasarkan tingkat validitas dari para ahli, tingkat keterterapandantingkatketerbacaanyang tinggi melalui uji coba produk. Instrumen pengumpulan data yang digunakan antara lain lembar validasi para ahli, angket tanggapan siswadan angket tanggapan guru. Temuan penelitian dan pengembangan menunjukkan bahwa hasil uji validasi para ahli menyatakan sangat valid dengan skor rata-rata sebesar 4,11. Tingkat keterterapan produk dengan skor rata-rata sebesar 4,27. Tingkat keterbacaan produk dengan skor rata-rata sebesar 4 .
\end{abstract}

Kata kunci : Asesmen Autentik, Pembelajaran PKn

Pendidikan Kewarganegaraan (PKn) adalah salah satu mata pelajaran pokok yang harus ditempuh oleh siswa sekolah dasar (SD). Tujuan utama mata pelajaran PKn di SD yaitu memfokuskan pada pembentukan warga negara Indonesia yang cerdas, terampil, dan berkarakter.Salah satu kunci penting dalam pencapaian tujuan pembelajaran PKn adalah guru. Guru dituntut untuk menanamkan nilai-nilai yang tertuang dalam tujuan pembelajaran PKn. Indikator keberhasilan dalam mencapai tujuan pembelajaran PKn tergantung pada kemampuan penilaian guru terhadap kompetensi siswa. Pada prinsipnya penilaian dalam pembelajaran PKn tidak berbeda dengan penilaian dalam mata pelajaran lainnya, hanya penekanan penilaian dalam mata pelajaran PKn lebih pada aspek afektif (Winataputra, 2008:125). Hal tersebut dapat diartikan penilaian aspek afektif wajib dilakukan karena untuk mengetahui keberhasilan kompetensi afektif dalam mata pelajaran PKn.

Selama ini yang terjadi di lapangan, penilaian pembelajaran PKn hanya dilakukan pada aspek kognitif belum menilai aspek afektif. Hal ini 
berakibat belum diketahui keberhasilan aspek afektif. Hasil angket yang diberikan kepada guru menunjukan penilaian pembelajaran PKn lebih sering menggunakan tes objektif. Guru menekankan pada penilaian yang mengukur pengetahuan siswa sehingga penilaian sikap siswa belum terlaksana dengan baik. Hal ini dikuatkan dengan hasil angket yang diperoleh dari siswa ditemukan bahwa penilaian pembelajaran cenderung menggunakan bentuk soal pilihan ganda dan uraian. Pada soal pilihan ganda taksonomi yang digunakan guru lebih cenderung pada taksonomi domain kognitif padahal kompetensi dasar menuntut pada kemampuan afektif. Keadaan ini terjadi karena kurangnya pemahaman guru tentang penilaian pembelajaran.

Guru melakukan penilaian sikap dengan pengamatan secara tak terstruktur. Guru belum melakukan penilaian konsistensi perkembangan sikap. Hal ini dilakukan karena terbatasnya pengetahuan dan keterampilan guru sehingga guru mengalami kesulitan dalam mengembangkan jenis penilaian. Selain itu, belum adanya contoh penilaian yang menggambarkan kemampuan sikap siswa menjadi kendala guru dalam melakukan penilaian.

Berdasarkan pengumpulan informasi di atas, dapat disimpulkan permasalahan yang terjadi, yaitu: (1) penilaian cenderung hanya aspek kognitif sehingga aspek afektif belum terlaksana dengan baik, (2) belum ada penilaian yang menggambarkan kemampuan sikap siswa, dan (3) guru belum melakukan penilaian konsistensi perkembangan sikap. Kondisi ini tentu tidak sesuai dengan tujuan mata pelajaran PKn yang mempunyai misi menanamkan karakter dan penilaiannya cenderung menekankan aspek afektif.

Peneliti berpendapat solusi permasalahan di atas adalah perbaikan mutu evaluasi pembelajaran melalui perbaikan jenis asesmen. Evaluasi pembelajaran merupakan proses pendeskripsian, penafsiran, dan pengambilan keputusan tentang kemampuan siswa berdasarkan data yang dihimpun melalui proses asesmen untuk keperluan penilaian (Akbar, 2013:88). Perbaikan jenis asesmen merupakan langkah nyata untuk memperbaiki evaluasi pembelajaran karena asesmen memberikan informasi tentang kemampuan siswa selama proses pembelajaran sehingga membantu guru untuk mengambil keputusan. Hal ini sejalan pendapat Bull (dalam
Wahyuni, 2010:29) asesmen merupakan suatu kegiatan pengumpulan informasi untuk mengambil sebuah keputusan.

Menurut Brown (2004:13) asesmen dibedakan menjadi dua, yaitu asesmen tradisional dan asesmen autentik. Asesmen tradisional menekankan penguasaan pengetahuan siswa sebagai hasil belajar, sedangkan asesmen autentik menekankan pada proses dan hasil belajar. Marzano (dalam Achmad, 2011:14) menjelaskan bahwa asesmen autentik meliputi penekanan pada kemampuan nyata siswa, mengembangkan seluruh kemampuan siswa melalui kegiatan pembelajaran bersifat konstruktivis dan tidak menggunakan sistem tes. Jenis asesmen autentik merupakan solusi karena menekankan proses belajar siswa. Johnson (2002:165) memaparkan bahwa asesmen autentik memberikan kesempatan luas pada siswa untuk menunjukan apa yang telah mereka pelajari selama pembelajaran. Asesmen autentik membuat siswa sadar akan pentingnya proses belajar.

Menurut Wahyuni (2012:68) asesmen autentik mempunyai 6 bentuk, yaitu: (1) asesmen kinerja, (2) asesmen portofolio, (3) asesmen proyek, (4) asesmen teman sejawat, (5) asesmen diri, dan (6) asesmen sikap. Bentuk asesmen autentik yang cocok dalam permasalahan ini, yaitu asesmen kinerja dan asesmen sikap karena ketika sikap siswa sudah konsisten akan mempengaruhi kinerja siswa sehingga menjadi solusi pada masalah yang terjadi. Asesmen kinerja dan asesmen sikap dilakukan selama proses pembelajaran berlangsung. Selain itu, dua bentuk asesmen ini melibatkan siswa untuk meningkatkan kinerja, pembuatan hasil karya, dan sikap dalam proses pembelajaran.

Asesmen kinerja adalah penilaian belajar siswa yang meliputi penilaian bentuk kegiatan siswa berupa tulisan, sikap maupun produk (Danielson \& Marquez, 1998:1). Hal ini dapat diartikan asesmen kinerja dapat memaksimalkan penilaian aspek afektif. Menurut Widodo (2009:34) keunggulan asesmen kinerja, menggambarkan keadaan sesungguhnya siswa dalammembuat produk. Penilaian seperti ini memiliki karakteristik dasar yaitu siswa diminta untuk mendemonstrasikan kemampuan dalam mengkreasikan suatu produk.

Arifin (2011:191) menyatakan bahwa asesmen sikap adalah penilaian yang dilakukan pada berbagai objek sikap seperti sikap terhadap 
proses pembelajaran. Penilaian terhadap sikap dapat dilakukan dengan observasi langsung sehingga penilaian bersifat nyata yang dilakukan oleh siswa (Wahyuni, 2012:82). Penilaian didasarkan pada indikator sikap yang muncul dalam setiap kegiatan pembelajaran sehingga dapat diukur konsistensinya. Jika siswa mulai konsisten dalam kemunculan indikator sikap, maka dapat diartikan siswa mulai membudayakan. Hal ini sejalan dengan kriteria yang dikembangkan Kemendiknas (2010:9-10) yaitu belum terlihat (BT), mulai terlihat (MT), mulai berkembang (MB), dan membudaya karakter (MK) yang masing-masing mempunyai konversi skor serta deskripsi konsistensi.

Penentuan sikap dalam asesmen sikap dilakukan dengan menganalisis Standar Kompetensi (SK) dan Kompetensi Dasar (KD) yang bersifat afektif. Sikap yang akan diukur dalam penelitian ini, yaitu tanggung jawab, jujur dan kreatif. Alasan pemilihan tiga sikap tersebut menyesuaikan materi pada Kompetensi Dasar (KD) 1.3 menunjukan contoh-contoh perilaku menjaga keutuhan Negara Kesatuan Republik Indonesia. Sikap tanggung jawab, jujur, dan kreatif merupakan jenis sikap hubungan dengan diri sendiri yang akan diintegrasikan dalam proses kegiatan pembelajaran.

Berdasarkan hal di atas dikembangkan perangkat asesmen autentik dalam pembelajaran PKn Kelas SD yang mempunyai tingkat kevalidan, keterterapan, dan keterbacaan. Asesmen dianggap valid jika mendapat kriteria valid dari ahli materi dan ahli evaluasi pembelajaran. Asesmen dianggap mempunyai keterterapan jika guru dan siswa mudah dalam menggunakan. Asesmen dikatakan mempunyai keterbacaan jikaguru dan siswa mudah memahami petunjuk dan mengerjakannya.

Asesmen autentik belum banyak dikembangkan di sekolah dasar terutama pada mata pelajaran PKn. Berdasarkan hasil penelitian terdahulu yang dilakukan Haryani, dkk (2012) menunjukkan bahwa instrumen yang telah dibuat sudah menunjukkan kemudahan dalam menilai siswa dan menunjukan kemampuan siswa dalam membaca puisi. Hubungan dengan penelitian sekarang yaitu variabel penelitian sama pada asesmen pembelajaransehingga penelitian ini relevan dengan penelitian sekarang. Hasil penelitian Wicaksono (2012) menemukan bahwa produk asesmen autentik memberikan gambaran kemampuan siswa dan penilaian proses belajar siswa dapat terukur dengan jelas. Hubungan dengan penelitian sekarang terdapat variabel penelitian sama yaitu asesmen autentik sehingga penelitian ini relevan dengan penelitian sekarang.Penelitian yang dilakukan Bundu (2013) dengan judul Model Asesmen Keterampilan Proses dan Nilai Karakter Berbasis E-Portfolio di Sekolah Dasar menyimpulkan bahwa model asesmen keterampilan proses berbasis nilai karakter mudah digunakan dan dimodifikasi oleh guru.

\section{METODE}

Metode penelitian dan pengembangan yang digunakan dalam mengembangan produk perangkatasesmenautentik menggunakan model pengembangan model Borg \& Gall (1983). Penelitian pengembangan ini menggunakan model pengembangan Borg \& Gall yang telah dimodifikasi menjadi: (1) pengumpulan informasi, (2) perencanaan, (3) pengembangan produk, (4) validasi ahli, (5) uji coba lapangan,(6) produk akhir.

Uji coba kelayakan produk yang dilakukan meliputi: (1) uji validasi dari ahli isi/ materidanahlievaluasipembelajarandan (2) uji coba lapangan. Subjek uji coba meliputi ahli isi/materi, ahli evaluasipembelajaran, guru kelas V dan siswa kelas V SDN Sawojajar 2 Kota Malang. Instrumen pengumpulan data yang digunakan antara lain lembar validasi para ahli, angket tanggapan siswadan angket tanggapan guru. Analisis data yang digunakan dalam penelitian dan pengembangan ini yaitu analisis deskriptif kualitatif dan deskriptif kuantitatif.

Ahli isi/materi adalah dosen Pendidikan Pancasila dan Kewarganegaraan.Hasil perolehan uji validasi perangkatasesmenmenunjukkan perolehan sebesar 3,95 dan hasil tersebut mendapat kriteria cukup valid. Ahli evaluasipembelajaran dipercayakan sebagai validatorevaluasipembelajarandosen Evaluasi Pembelajaran Fakultas Sastra. Hasil perolehan uji validasi perangkatasesmensiswa menunjukkan perolehan hasil sebesar 4,28. Setelah dikonversi pada tabel tingkat kelayakan, produk tersebut termasuk dalam kategorivalid.

Subjek dalam uji lapangan ini yaitu guru kelas V dan seluruh siswa kelas VSDN Sawojajar 2 Kota Malang yang berjumlah 45 orang. Data uji coba lapangan bertujuan untuk mengetahui tingkat keterterapandanketerbacaanperangkatasesmen. 
Tingkat keterterapandiambildariangkettanggapan guru dansiswa. Tanggapan guru dikumpulkan melalui angket yang diberikan peneliti pada guru kelas V, Ibu Yuamah, S.Pd sebagai pengguna perangkatasesmen. Hasil tanggapan guru terhadap keterterapanperangkatasesmen menunjukkan perolehan nilai dengan sebesar 4,3 . Sedangkan hasil tanggaan siswamenunjukkan presentase skor sebesar 4,25. Setelah dikonversi, skor tersebut sebesar 4,27 berkategori sesuai.

Tingkat keterbacaan diambil dari angket tanggapan guru dansiswa. Tanggapan guru dikumpulkan melalui angket yang diberikan peneliti pada guru kelas $\mathrm{V}$ sebagai pengguna perangkatasesmen. Hasil tanggapan guru terhadap keterterapanperangkatasesmen menunjukkan perolehan nilai dengan sebesar 4. Sedangkan hasil tanggaan siswamenunjukkan presentase skor sebesar 4. Setelah dikonversi, skor tersebut sebesar 4 berkategori sesuai.

\section{HASIL DAN PEMBAHASAN}

Kevalidanperangkatasesmendiambildari hasil validasi ahli yang merupakan data yang paling penting untuk merevisi produk agar lebih sempurna.Berdasarkan hasil uji ahli evaluasi pembelajaran diperoleh nilai sebesar 4,28 yaitu nilai tersebut valid. Saran dari ahli evaluasi pembelajaran yaitu asesmen sikap harus mengukur tingkat konsistensi siswa minimal 4 kali dalam 1 semester sehingga diketahui pembentukan sikap. Hal ini sejalan Kemendiknas (2010:9-10) bahwa deskripsi sikap pada pedoman penskoran hasil belajar afektif mengukur tingkat konsistensi sikap siswa. Selain itu, pada jenjang pendidikan sekolah dasar (SD) porsi sikap lebih dominan dari pada pengetahuan dan keterampilan. Hal ini sejalan dengan gambar 5.1 tentang keseimbangan antara sikap, keterampilan dan pengetahuan dalam pembelajaran menurut Marzano (dalam Kemendikbud, 2013:9).Asesmen kinerja sudah menunjukan kemampuan siswa dalam membuat produk. Produk yang dihasilkan berupa peta sederhana, semboyan dan esai. Siswa lebih antusias dalam proses pembelajaran dan hasil kegiatan siswa lebih autentik. Hal ini sejalan Hibbard (dalam Widodo, 2009:34) karakteristik asesmen kinerja yaitu keautentikan. Selain itu, asesmen kinerja dapat menggambarkan keadaan sesungguhnya siswa dalammembuat produk.
Hasil uji ahli materi atau isi mendapatkan nilai 3,95 termasuk dalam kualifikasi cukup valid, sehingga hanya memerlukan revisi kecil. Revisi yang dilakukan berkaitan dengan RPP yang indikator pembelajaran dibuat lebih operasional sesuai dengan konteks sikap. Hal ini sejalan dengan pendapat Ruminiati (2007:115) yang mengatakan bahwa PKn merupakan pendidikan yang cenderung pada pendidikan aspek afektif tetapi tanpa meninggalkan aspek yang lain. Selain itu, menurut Winataputra (2008:125) secara umum penilaian dalam PKn sama dengan mata pelajaran lainnya, tetapi penekanannya cenderung pada aspek afektif. Dengan demikian perubahan dilakukan pada indikator pembelajaran agar lebih operasional dan disesuaikan dengan konteks sikap yang akan diukur.

Perangkat asesmen autentik ini belum memakai Kurikulum 2013 tetapi masih KTSP KD 1.3 menunjukan contoh-contoh perilaku dalam menjaga keutuhan Negara Kesatuan Republik Indonesia. Hal ini dilakukan karena menyesuaikan kondisi lapangan yang mengalami masa perubahan kurikulum dari KTSP ke Kurikulum 2013. Pada Kurikulum 2013 materi ini tetap muncul pada Kompetensi Inti 2 (sikap) KD 2.1 menunjukkan perilaku, disiplin, tanggung jawab, percaya diri, berani mengakui kesalahan, meminta maaf dan memberi maaf yang dijiwai keteladanan pahlawan kemerdekaan RI dalam semangat perjuangan, cinta tanah air, dan rela berkorban sebagai perwujudan nilai dan moral Pancasila. KD 2.4 menunjukkan perilaku cinta tanah air Indonesia dalam kehidupan di rumah, sekolah, dan masyarakat. Dengan demikian dilihat dari kemunculan materi pada Kurikulum 2013 maka perangkat asesmen autentik ini masih mempunyai kemanfaatan jika Kurikulum 2013 sudah diterapkan secara penuh di sekolah dasar.

Keterterapandanketerbacaandilihatdarihasil uji coba lapangan menyatakan bahwa perangkat asesmen ini memiliki keterterapan memperoleh skor 4,2 dengan kategori sesuai, sedangkan hasil keterbacaan memperoleh skor 4 dengan kategori sesuai. Saran dari guru rekapitulasi nilai siswa dibuatkan software agar mempermudahkan guru dalam menghitung dan memproses nilai siswa. Dengan demikian proses rekapitulasi nilai siswa lebih cepat dan sederhana. Hasil penggunaan software rekapitulasi ini dapat dicetak secara klasikal atau individu sehingga mempermudah guru dalam 
laporan ke orang tua atau dokumentasi hasil nilai siswa. Skor yang dicapai pada uji lapangan cukup tinggi hal tersebut sejalan dengan teori keterterapan menurut Brown (2004:5) alat penilaian dikatakan memiliki keterterapan yang tinggi, jika dapat dilakukan guru pada kondisi apapun. Hal ini menunjukan perangkat asesmen ini sesuai dengan teori keterterapan. Selain itu, keterbacaan menurut Harjdasujana (1999:10) kalimatnya mudah dipahami, paragraf-paragrafnya memiliki kesatuan dan isi yang memadai, babbabnya runtut dan gaya bahasanya sederhana. Skor yang diperoleh dari lapangan perangkat asesmen menunjukan sesuai dengan teori keterterapan karena petunjuk pembelajaran dan prosedur penilaian dapat dipahami oleh guru dan siswa.

Berdasarkan hasil penelitian yang telah dilakukan dapat disimpulkan perangkat asesmen autentik ini memiliki kelebihan dan kelemahan. Kelebihan perangkat asesmen autentik yang telah disusun adalah sebagai berikut.

Instrumen asesmen sikap dapat melihat konsistensi sikap tanggung jawab, sikap jujur, dan sikap kreatif dalam kegiatan pembelajaran yang meliputi: (a) simpulan rapor dan deskripsi dalam lembar asesmen sikap sehingga diketahui hasil pembentukan sikap siswa, (b) asesmen kinerja menggambarkan keadaan sesungguhnya siswa dalam membuat produk, (c) siswa antusias dalam pembelajaran karena kegiatan lebih autentik dengan membuat peta sederhana, membuat semboyan, dan membuat esai, (d) rekapitulasi nilai siswa menggunakan software sehingga memudahkan guru dalam memproses nilai. Kelemahan perangkat asesmen autentik ini adalah:

\section{DAFTAR RUJUKAN}

Achmad, R. 2011. Penerapan Asesmen Auntentik Berbasis Konstruktivisme untuk Meningkatkan Keterampilan Proses dan Hasil Belajar Biologi di Kelas X-1 SMAN 2 Malang. Tesis tidak diterbitkan. Malang: PPs UM.

Akbar, S. 2011. Pendidikan Karakter Bangsa Melalui Pendekatan Menyeluruh. Malang: FIP UM.

Akbar, S. 2013. Instrumen Perangkat Pembelajaran. Bandung: PT. Remaja Rosda Karya. (a) guru membutuhkan waktu yang lebih lama dalam penskoran asesmen kinerja yang digunakan, (b) terlalu banyak siswa menjadi kendala penilaian sikap dalam proses pembelajaran.

Produk perangkatasesmenautentik yang telah dikembangkan dapat digunakan secara maksimal jika guru dan siswa mempelajari terlebih dahulu agar memudahkan dalam proses pembelajaran. Produk ini juga dapat dimanfaatkan untuk kalangan lebih luas dengan penyesuaian terutama penyesuaian pada karakteristik siswa sebagai pengguna. Lebih lanjut perangkat asesmen ini dapat dikembangkan penilaian sikap dikembangkan dalam kegiatan-kegiatan di luar kelas, hasil penilaian konsistensi sikap dilakukan lebih dari 4 kali pengamatandan asesmen sikap dapat dikembangkan pada sikap lainnya sesuai dengan Kompetensi Dasar.Selain itu, dalam implementasi kurikulum 2013 perangkat asesmen autenti kini perlu dilakukan penyesuaian agar dapat digunakanlebihmaksimal.

\section{SIMPULAN}

Berdasarkan hasil uji ahli evaluasi pembelajaran diperoleh nilai sebesar 4,28 yaitu nilai tersebut valid. Hasil uji ahli materi atau isi mendapatkan nilai 3,95 termasuk dalam kualifikasi cukup valid, sehingga hanya memerlukan revisi kecil. Keterterapandanketerbacaandilihatdarihasil uji coba lapangan menyatakan bahwa perangkat asesmen ini memiliki keterterapan memperoleh skor 4,2 dengan kategori sesuai, sedangkan hasil keterbacaan memperoleh skor 4 dengan kategori sesuai.

Arifin, Z. 2009. Evaluasi Pembelajaran. Bandung: PT. Remaja Rosda Karya.

Borg, W.R, and Gall, M.D.1983. Education Reseacrh An Introduction (Fourth Edition). New York: Longman Inc.

Brown, H.D. 2004. Language Assesment: Pricipples and Classroom Practice. New York: Pearson Education Inc.

Bundu, P. 2013. Model Asesmen Keterampilan Proses dan Nilai Karakter Berbasis EPortfolio di Sekolah Dasar. Jurnal Ilmu Pendidikan. 
Danielson, Charlote, \& Marquez, Elizabeth. 1998. A Collection of Perfomance Task And Rubrics: High School Mathematics. Larchmont, Ny: Eye On Education.Inc.

Gall, M. D. dkk. 2003. Educational Research An Introduction (7th ed.). New York: Person Education Inc.

Harjdasujana, dkk. 1999. Evaluasi Keterbacaan Buku Teks Sunda untuk SD di Jawa Barat. Jakarta: Depdikbud.

Harsiati, T. 2003. Penerapan Pendekatan Konstruktivis dan Peneilaian autentik (Portofolio) dalam Upaya Peningkatan Kualitas Perkuliahan Evaluasi PBI pada Mahasiswa JPBSI UM.Laporan Hasil Penelitian LPTK UM.

Harsiati, T. 2003. Penerapan Penilaian Otentik (Authentic Assesment) Berbentuk Portofolio dalam Upaya Peningkatan Proses dan Hasil Penulisan Karya Ilmiah pada Perkuliahan Bahasa Indonesia Keilmuan di Universitas Negeri Malang. Malang: Lemlit UM.

Harsiati, T. 2011. Penilaian dalam Pembelajaran (Aplikasi pada
Pembelajaran Membaca dan Menulis). Malang: Percetakan Universitas Negeri Malang.

Haryani, S. 2012. Membangun Metakognisi dan

Karakter Calon Guru melalui Pembelajaran Praktikum Kimia berbasis Masalah. Semarang: UNNES PRESS

Ruminiati. 2010. Pembelajaran PKn. Yogyakarta: Cipta Media

Wahyuni, S. 2012. Penilaian Autentik Teori dan Praktik. Yogyakarta: Ciptamedia

Widodo, S. 2008. Psikologi Belajar (Edisi Revisi). Jakarta: Rineka Cipta

Winataputra, U. S. 2012. Pendidikan Kewarganegaraan dalam Perspektif Pendiidkan untuk Mencerdaskan Kehidupan Bangsa (Gagasan, Instrumentasi, dan Praksis). Bandung: Widya Aksara Press

Wucaksono, V. 2013. Pengembangan Asesmen Autentik dalam Proses dan Hasil Mata Pelajaran IPS. Yogyakarta: Rosdakarya 